\title{
Personality Type and Learned Helplessness of Senior High School Students in a Catholic School
}

\author{
Leni Rose G. Julag-ay ${ }^{1}$ and Chris Feli Joy P. Tajonera ${ }^{2}$ \\ 1,2University of Negros Occidental-Recoletos, Bacolod City, Philippines
}

\begin{tabular}{l} 
Article history \\
Submitted: 25 June 2020 \\
Revised: 11 November 2020 \\
Accepted: 12 November 2020 \\
\hline Keywords \\
Guidance and Counseling \\
Personality Type \\
Learned Helplessness \\
Senior High School Students \\
Descriptive-Correlational \\
Bacolod City
\end{tabular}

Introduction. People's personality types are combinations of differences wherein characteristics, behavior, and thoughts work dynamically. Each one's experiences with uncontrollable and disappointing events may lead them to feelings of helplessness and make them realize and choose not to change the situation. As a school guidance and counseling staff, the researcher, happens to have one-on-one or group sessions, testing, and surveys to students in senior high school, which transpired concerns regarding the academic, student-teacher relationship, peers, and others. The student's ability to deal with the challenges they encountered triggered the conduct of this study since some know how to manage their concerns, but some feel helpless and fail to try. In this event, it may result in poor performance in school and the students' negative behavior. Thus, the study aims to determine the personality type and degree of learned helplessness of senior high school students of a Catholic school in Bacolod City when they are taken as a whole and grouped according to sex, strand, and academic performance. Likewise, it explores whether a relationship exists between the variables and learned helplessness.

Methods. The study employed a descriptive-correlational design. Using stratified random sampling, 400 senior high school students of a Catholic university in Bacolod City participated in the study. The Learned Helplessness Scale (Nelson \& Quinless, 1988) and Personality Temperament Test (LaHaye, 1988) were utilized to measure respondents' degree of learned helplessness and personality type, respectively. Mean, Standard Deviation and Chi-square test were used for data treatment and analysis.

Results. The findings reveal that most of the students have choleric personality type which indicates that they can be dominant and leader-like. On the other hand, the degree of learned helplessness of students is low wherein it indicates that students can handle challenges and use these challenges as their motivation. Looking at the findings, it can be noted that students' personality as choleric may have contributed to their low tendency to be helpless. However, no significant relationships between the variables and personality type exist. This indeed implies that regardless of personality, learned helplessness may trigger favorably or unfavorably. Being choleric who is in control and organized could not be solely related to having low tendencies of being helpless. There might be other factors which interplay with the natural tendencies of every student to deal with academic challenges and this is not just because of their personality. Moreover, high tendency of learned helplessness of students may be equalized to a different challenge like anxiety or depression, family problems, relationships or anything to do with being resilient. These challenges seemed to be greatly influencing one's behavior to seek help. Furthermore, the personality type, degree of learned helplessness, and the aforementioned variables have no significant relationship with one another. It is because regardless of being male or female, achiever or not, as well as on their different career tracks, each one has different ways of coping with their problems and concerns. In this regard, the empathetic understanding of the guidance counsellor will play an important role in making the students ask help when needed and learn not to feel helpless when necessary for they face challenges head on. 
Conclusion. Since most students were choleric, they are eager to achieve their goals and plans. However, it cannot be denied that there are challenges along the way that might contribute in making them feel helpless. With this, students need to know how to address such feelings and use them as their motivation in improving themselves. Overcoming these challenges could make them believe that everything is possible when they and the people around them continuously support and help them achieve their goals.

Practical Value of the Paper. The findings of the study will serve as a guide in designing and implementing the plan of action, which is the personality development program for senior high school students to help them understand their personalities and become their better versions. Also, this will significantly contribute to the local literature regarding personality type and learned helplessness of the students.

\section{References}

Ackerman, C. (2019). Learned Helplessness: Seligman's Theory of Depression (+ Cure). https://positivepsychology. com/learned-helplessness-seligman-theory-depression-cure/.

Aydogan, H. (2016). A Psycholinguistics Case Study: The Relations of Learned Helplessness, Locus of Control, and Attitudes towards English with Academic Success. Inonu University Journal of the Faculty of Education, 17(3), 177-183. DOI: 10.17679/inuefd.17391488.

Bojanowska, A., \& Zalewska, A. M. (2017). Happy temperament? Four types of stimulation control are linked to four types of subjective well-being. Journal of Happiness Studies, 18(5), 1403-1423.

Buttò, C., Buzzai, C., Costa, S., Filippello, P., \&Sorrenti, L. (2018) Learned helplessness and mastery orientation: The contribution of personality traits and academic beliefs, Nordic Psychology, 70:1, 7184, DOI: 10.1080/19012276.2017.1339625.

Flavier, C. (2018). Challenges and Self-efficacy of Senior High School Students in LCC Silvercrest: Basis for Guidance Enrichment Program. Institutional Research, Guidance, and Counseling Department.

Gul, M., \& Malik, F. (2018). Development and Validation of Stressful Life Events Scale for Children in Pakistan. Pakistan Journal of Psychological Research, 33(1), 239-256.

Hwang, J. (2019). Relationships among Locus of Control, Learned Helpless, and Mathematical Literacy in PISA 2012 : focus on Korea and Finland. Large-scale Assess. Educ 7, 4 doi:10.1186/s40536-019-0072-7.

LaHaye, T. (1988). Why Do You Act the Way You Do? United States: Tyndale Momentum.

Martinez, D. A. (2017). Personality Types, Affective Filters, and English Proficiency of Grade Ten Students in Davao City. Tin-aw, 1(1). Retrieved fromhttp://ejournals.ph/form/cite.php?id=13476.

Nelson, M. \& Quinless, F. (1988). Development of a Measure of Learned Helplessness. University of WisconsinMadison, School of Nursing. 600 Highland Avenue, Madison, Wisconsin.

\section{Correspondence:}

Leni Rose G. Julag-ay [leniroseju@gmail.com]

https://orcid.org/0000-0002-9404-3831 